\title{
Marketing of poultry eggs in Ondo West Local Government Area of Ondo State,
} Nigeria

*Ibidapo, I., *Ogunsipe, M. H. and **Owombo, P. T.

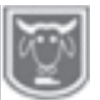

*Department of Agricultural Science, Adeyemi College of Education, Ondo. **Department of Agricultural Economics and Extension Olusegun Agagu University of Science and Technology, Okitipupa, Nigeria.

Abstract *(ibidapo68@gmail.com)

The study investigated the marketing of poultry-eggs in Ondo-West local government area of Ondo State, Nigeria. The multi-stage sampling technique was employed in the selection of one hundred and twenty-five (125) poultry-egg marketers for the study. Primary data collected with the aid of structured questionnaire were analysed using descriptive statistics, gross margin analysis and ordinary least square regression analysis. Result showed the mean age of respondents as $44.2 \pm 9.7$ years, $63.2 \%$ were female and $36.8 \%$ were male and $72.0 \%$ were married. The mean household size was $7 \pm 3$ members and $58.4 \%$ had secondary education. Price fluctuation constitutes a major challenge in poultry-egg marketing. The gross margin was 48611.37 . The regression analysis revealed that stock size (number of creates), cost price, transportation cost and labour cost were the significant variables influencing the gross margin in poultry-egg marketing in the study area. Marketing of poultry-egg has improved the average household means of livelihoods and generate income. Hence, poultry-egg marketing should be encouraged in terms of access to credit, information and provision of storage facilities.

Keywords: gross margin, marketing, poultry-egg, profitability.

La Commercialisation des œufs de volaille dans la zone de gouvernement local de L'Ouestd'Ondo de l'État d'Ondo, Nigeria

Résumé

$\bar{L}$ 'étude portait sur la commercialisation des eufs de volaille dans la zone de gouvernement local de l'Ouest de l'Ondo dans l'État d'Ondo, au Nigéria. La technique d'échantillonnage en plusieurs étapes a été utilisée pour sélectionner cent vingt-cinq (125) commerçants d'œufs de volaille pour l'étude. Les données primaires collectées à l'aide d'un questionnaire structuré ont été analysées à l'aide de statistiques descriptives, d'une analyse de la marge brute et d'une analyse de régression des moindres carrés ordinaires. Les résultats ont montré que l'âge moyen des répondants était de 44,2 \pm 9,7 ans, 63,2\% étaient des femmes et 36,8\% étaient des hommes et 72,0\% étaient mariés. La taille moyenne des ménages était de $7 \pm 3$ membres et $58,4 \%$ avaient une éducation secondaire. La fluctuation des prix constitue un défi majeur dans la commercialisation des oufs de volaille. La marge brute était de \$48611.37. L'analyse de régression a révélé que la taille du stock (nombre de caisses, prix, coût de transport et coût de la main-d'œuvre étaient les variables importantes influençant la marge brute de commercialisation des oufs de volaille dans la zone d'étude. La Commercialisation des oufs de volaille a amélioré les moyens de subsistance moyens des ménages et constitue un moyen de générer des revenus. Par conséquent, la commercialisation des oufs de volaille doit être encouragée en termes d'accès au crédit, d'information et de fourniture d'installations de stockage.

Mots clés : marge brute, commercialisation, œuf de volaille, rentabilité. 


\section{Marketing of poultry eggs in Ondo West Local Government Area of Ondo State}

\section{Introduction}

The marketing of poultry-eggs has been given much attention in both urban and rural areas of Ondo State and Nigeria in general. This is not unconnected with the importance of egg in the diet of an average Nigerian and consumption in every home. Poultry-eggs rank second to cow milk in terms of nutritive value and are the most economically produced animal protein (Nahid and Mohammad, 2015). Animal protein is an essential part of human nutrition because of its biological significance. Iwena (2007) reported that proteins are required for the growth of young ones, formation of gametes in reproduction, formation of digestive juices, repair of worn-out tissues or cells, production of anti-bodies as well as enzymes and hormones in the body. Poultry-egg marketing forms a good source of income, employment and vital source of food (protein) in the households. Marketing of poultry-eggs like other agricultural products serves as means of livelihoods in both the rural areas and the urban centers. Tijani et al. (2006) posited that animal proteins are more biologically complete than vegetable proteins with regards to their amino-acids composition. The sales of poultry-eggs contributed about $10.36 \%$ in the livestock sub-sector to the Gross Domestic Product (GDP) in the Nigeria economy (Central Bank of Nigeria, 2010). Eggs are a major sources of animal protein in human diet. According to Okafor et al. (2007) poultry goes a long way in providing animal protein for the populace because it yields quickest returns and provides for meat and eggs in a very short time. Poultryeggs are among the most versatile food in the kitchen of an average home, and it can be served in several ways on their own, eggs add texture and moisture to baked foods and complement both sweetened savoury dishes. In the diet, poultry-eggs can also boast of rich nutritional profile, provide a wide range of vitamins, minerals, and other nutrients, however, it is low calorie content. According to Dietary for Americans 20152020, Poultry-eggs are good sources of inexpensive high quality protein. However, despite the relative importance of eggs as sources of food, protein, income and means of livelihoods to the people, the marketing and distribution of poultry-eggs is beset by serious problems both in the rural and urban areas of the country and the study area in particular. These problems include; price fluctuations, high cost of transportation, inadequate supply, and high cost of feeding, poor availability of labour, inconsistent government policies on marketing agricultural products, among others. According to Olanloye (1998) and Nahid and Mohammed (2015) farm product marketing activities is hampered by; price fluctuations, product glut, and inadequacy and poor transportation. Malnutrition and hunger have remained among the most critical problems facing the world poor. Moreover, the dearth in the quantity and quality of dietary protein supply in Nigeria is a challenge that is beyond dependence on plant protein source alone. Most countries in sub-Saharan Africa including Nigeria are faced with the problem of insufficient poultry-egg production and protein deficiency. Despite the high demand for eggs in the markets, there has been serious problem of inadequacy in meeting the needs of the consumers. Hence, the need to investigate the economic analysis of poultry-egg marketing, identify the challenges facing poultry-egg marketing, determine the profitability of poultry-egg marketing and identify factors influencing gross margin poultry-egg marketing in Ondo-West local government area of Ondo State, Nigeria.

\section{Materials and methods}

This study was conducted in Ondo-West Local Government Area of Ondo State 


\section{Ibidapo, Ogunsipe and Owombo}

Nigeria. The study area consists of 283, 672 people (NPC, 2006). The major occupation is primarily farming however trading and livestock production activities are also being practiced. The multi-stage sampling technique was employed in the selection of respondents. Stage one entailed a purposive selection of Ondo-West local government area due to accessibility and availability of poultry-egg marketers. Stage two consisted of the random selection of five major towns in the study area while stage three comprised the random selection of ten markets in the study area. The final stage consists of the random selection of one hundred and twenty-five (125) poultry-egg marketers for the study. Data collected with the aid of structured questionnaire were analysed using frequency count, simple percentage, mean, standard deviation, budgetary technique and ordinary least square (OLS) multiple linear regression model. Frequency count, simple percentage and mean were used to describe characteristics of respondents, budgetary technique was used to estimate profitability while OLS was used to determine factors influencing gross margin in poultry-egg marketing. It is assumed that the data collected fulfilled the assumption of multiple regression model, such as the absence of multicolinearity among explanatory variables, normally distributed error term with zero mean and constant variance and non-autoregressive disturbance (Greene, 2002). The OLS model postulated for the gross margin in poultry-egg marketing in the study area is presented as;

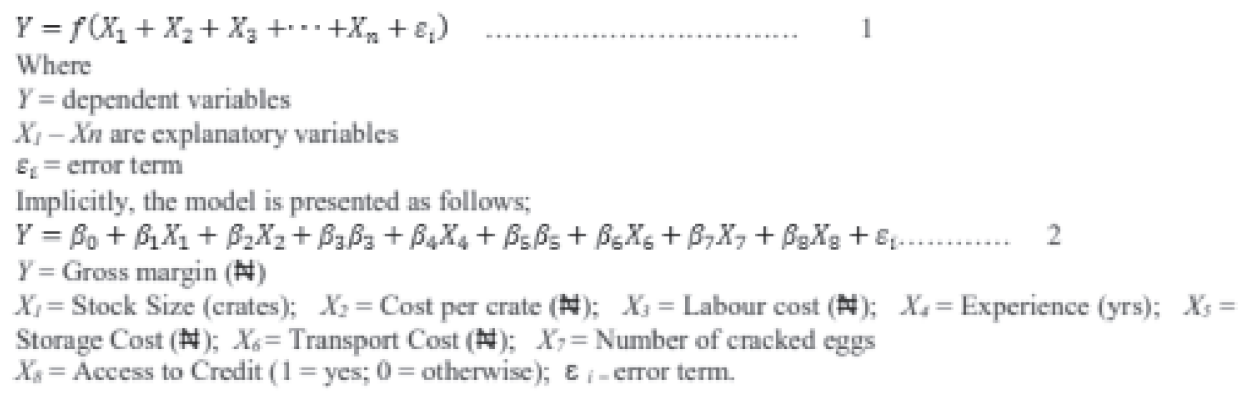

\section{Results and discussion}

The results (Table 1) showed that $57.6 \%$ of respondents were between $41-50$ years of age while $32.0 \%, 6.4 \%$, and $2.4 \%$ were between the age brackets of $31-40$ years, $51-60$ years and greater than 60 years, respectively. Also, $1.6 \%$ were less than or equal to 30 years of age. The mean age of poultry-egg marketers was $44.2 \pm 9.7$ years, which implies that poultry-egg marketers in the area were still at the economic active age. On gender, $63.2 \%$ were female and $36.8 \%$ were male. This indicates that poultry-egg marketing in the area is dominated mainly by female which is peculiar with the marketing of most agricultural produce. The marital status of the respondents indicated that, $72.0 \%$ were married while $12.0 \%, 9.6 \%$ and $6.4 \%$ were widowed, single and divorced, respectively. This implies that majority of the poultry-egg marketers were married which is a sign of responsibility in our traditional society. The household size revealed that, $52.0 \%$ of the poultry-egg marketers had between $5-10$ members per household while $41.6 \%, 4.8 \%$ and $1.6 \%$ had between 11 - 16 members, greater than 16 members and $1.6 \%$ had less than 5 members, respectively per household. The mean household size was $7 \pm 3$, indicating that poultry-egg marketers in the area had fairly large household size which is above the national average household size of 5 members per household (Olugbire, 2011). 
Table 1: Distribution of poultry-egg marketers by age, gender, marital status and household size

\begin{tabular}{lrccc}
$\mathbf{n}=\mathbf{1 2 5}$ & Frequency & Percentage & Mean & SD \\
\hline Variable & 2 & 1.6 & & \\
\hline Age (yrs) & 40 & 32.0 & & \\
$31-40$ & 72 & 57.6 & & \\
$41-50$ & 8 & 6.4 & 44.2 & 9.7 \\
$51-60$ & 3 & 2.4 & & \\
$>60$ & 79 & 63.2 & & \\
Gender & 46 & 36.8 & & \\
Female & & & & \\
Male & 12 & 9.6 & & \\
Marital Status & 90 & 72.0 & & \\
Single & 8 & 6.4 & & \\
Married & 15 & 12.0 & & \\
Divorced & & & & \\
Widowed & 28 & 22.4 & & \\
Household Size & 74 & 59.2 & & \\
$<5$ & 23 & 18.4 & & \\
$5-10$ & & &
\end{tabular}

Source: Field Survey, 2019

On the educational attainment of poultryegg marketers, the results showed that $58.4 \%$ had secondary education, $20.0 \%$ had primary education, while $12.0 \%$ and $9.6 \%$ had no formal education and tertiary education, respectively. The high proportion of literate members implies that the marketers were capable of accessing information, locating markets and engaging in marketing intelligence on poultry-egg marketing. The mean year of experience of the poultry-egg marketers was $9.4 \pm 4.6$ years. This indicates that the poultry-egg marketers in the study area were well experienced in egg marketing. On sources of capital for poultry-egg marketing, 58.6\% indicated the cooperative society as their source of credit while (21.6\%) obtained credit from money lenders to start egg marketing business, others, $12.0 \%$ and $8.0 \%$ patronised friends/relatives and commercial banks for capital to finance the egg marketing business, respectively. The use of cooperative society as source of credit by majority of poultry-egg marketers may not be unconnected with the timeliness of access, low interest on loans and easy mode of repayment by poultry-egg marketers compared to other sources of credit .On the quantity of poultry-egg sold (or stock) by marketers, $50.4 \%$ indicated that they sold between 30 and 50 crates while $24.0 \%$ sold between 51 and 70 crates of eggs, moreover, $12 \%, 9.6 \%$ and $4 \%$, respectively sold between 71 and 90 crates, less than 30 crates and more than 90 crates of poultry-eggs. This implied that there is much demand for poultry-eggs in the study area which help to boost their turnover in egg marketing.

Table 3 revealed the challenges facing poultry-egg marketers in the study area. Inadequate capital outlay accounted for $32.0 \%$ while price fluctuation in the price of poultry-egg in the market represented $48.8 \%$. This is in agreement with Nahid and Mohammed (2015) who identified price fluctuation and shortage of capital as some of the challenges in egg business. Others are; poor storage facilities represent $8.8 \%$, $6.4 \%$ and $4.0 \%$ indicated labour problems and small-size of the business as the challenges facing the poultry-egg marketers. 
Table 2: Distribution of poultry-egg marketers by education, marketing experience, sources of credit and crates of egg sold $(n=125)$

\begin{tabular}{lcccc}
\hline Variables & Frequency & Percentage & Mean & SD \\
\hline Education & 15 & 12.0 & & \\
No formal education & 25 & 20.0 & \\
Primary education & 73 & 58.4 & \\
Secondary education & 12 & 9.6 & \\
Tertiary education & 2 & 1.6 & \\
Marketing experience (yrs) & 65 & 52.0 & \\
$<5$ & 52 & 41.6 & \\
$5-10$ & 6 & 4.8 & 9.4 & \\
$11-16$ & & & \\
$>16$ & 73 & 58.4 & & \\
Sources of credit & 27 & 21.6 & & \\
Cooperative Society & 10 & 8.0 & \\
Money Lenders & 15 & 12.0 & \\
Commercial Bank & & & \\
Relatives/Friends & 12 & 9.6 & \\
Crates of eggs sold & 30 & 24.0 & \\
$<30$ & 65 & 50.4 & 5.6 & \\
$30-50$ & 15 & 12.0 & \\
$51-70$ & 5 & 4.0 & \\
$71-90$ & & & \\
$>90$ & & & \\
\hline Source: Fild Survey, 2019 & & & \\
\end{tabular}

Source: Field Survey, 2019

Table 3: Challenges facing poultry-egg marketers $(n=125)$

\begin{tabular}{lcc}
\hline Variables & Frequency & Percentage \\
\hline Challenges & & \\
Inadequate Capital & 40 & 32.0 \\
Price Fluctuations & 61 & 48.8 \\
Poor Storage facilities & 11 & 8.8 \\
Labour Problem & 5 & 4.0 \\
Small market size & 8 & 6.4 \\
\hline
\end{tabular}

Source: Field Survey, 2019

\section{Profitability analysis of poultry-egg marketing}

The profitability analysis in this study was determined using the gross margin analysis, net farm income and the cost benefit ratio thus;

Gross margin analysis (GM): $\mathrm{GM}=\mathrm{TR}-$ TVC .........2

Where; $\mathrm{GM}=$ Gross Margin, $\mathrm{TR}=$ Total Revenue and TR = Q.P. 3

$\mathrm{Q}$ represents the number of crates; $\mathrm{P}=$ Price per crate; and $\mathrm{TVC}=$ Total Variable Cost.

Net Income (NI): Net Income $=$ TR - TC .....4 Where, $\mathrm{TR}=$ Total Revenue; $\mathrm{TC}=$ Total Cost; Benefit-Cost Ratio (B/C): The Benefit-Cost ratio is used to determine the profitability of poultry-egg marketing business. It helps to ascertain the gain over every naira invested in the poultry-egg marketing. This is expressed as; TR/TC.

The result of the profitability analysis indicated that -48611.37 was realized as gross margin while -18065.56 was the net income (net profit). The return on a naira invested in poultry-egg marketing was 1.16. This showed that on every naira invested in the sale of poultry-egg marketing -0.16 was realized as gain. This indicated that the marketing of poultry-egg in the study area is profitable. However, the variable costs accounted for $71.6 \%$ in the cost of production while the fixed cost represented $28.4 \%$. 
Table 4: Profitability analysis for poultry-egg marketing

\begin{tabular}{|c|c|c|}
\hline Variables & Amount (\#) & Percentage (\%) \\
\hline Total Revenue & 125440.57 & \\
\hline \multicolumn{3}{|l|}{ Variable Costs } \\
\hline Purchase & 58375.36 & 54.4 \\
\hline Transportation & 8065.51 & 7.5 \\
\hline Cost of crates & 11850.75 & 11.0 \\
\hline Total Variable Cost (TVC) & 78291.62 & \\
\hline \multicolumn{3}{|l|}{ Fixed Cost } \\
\hline Rent & 24000.80 & 22.4 \\
\hline Security & 6545.01 & 6.1 \\
\hline Total Fixed Cost (TFC) & 30545.81 & \\
\hline Total Cost (TFC + TVC) & 107375.01 & \\
\hline \multicolumn{3}{|l|}{ Returns on Investment } \\
\hline Gross Margin & 48611.37 & \\
\hline Net income & 18065.56 & \\
\hline Benefit-Cost Ratio (B/C) & 1.16 & \\
\hline
\end{tabular}

Author's Computation, 2019.

Table 5: Regression analysis on determinants of gross margin in poultry-egg marketing

\begin{tabular}{lllll}
\hline Variables & Coefficient & Std. Error & T & Sig. \\
\hline Stock Size $\mathrm{X}_{1}$ & 4.918 & 1.512 & 3.253 & $0.002^{* * *}$ \\
Cost Price $\mathrm{X}_{2}$ & -3.897 & 0.344 & -11.324 & $0.000^{* * *}$ \\
Labour Cost $\mathrm{X}_{3}$ & $-9.680 \mathrm{E}-6$ & 0.000 & -1.682 & $0.095^{*}$ \\
Experience $\mathrm{X}_{4}$ & 0.133 & 0.102 & 1.299 & 0.197 \\
Rent/Storage Cost $\mathrm{X}_{5}$ & $-8.253 \mathrm{E}-6$ & 0.000 & -1.215 & 0.227 \\
Transportation Cost $\mathrm{X}_{6}$ & -0.395 & 0.132 & -2.994 & $0.003^{* * *}$ \\
Number of cracked eggs $\mathrm{X}_{7}$ & 0.133 & 0.102 & 1.297 & 0.197 \\
Credit access X & 0.383 & 1.064 & 0.360 & 0.719 \\
Constant & 20.091 & 2.073 & 9.691 & $0.000^{* * *}$ \\
F-Value & 29.425 & & & $0.000^{* * *}$ \\
$\mathrm{R}^{2}$ & 0.937 & & $\mathrm{AR}^{2}=$ & 0.891 \\
\hline Source: Auth & & &
\end{tabular}

Source: Author's Computation, $2019 * \& * * *$ significant at $10 \%$ and $1 \%$

Table 5 shows the regression analysis of the determinants of gross margin in poultryegg marketing in the study area. The linear, semi log and double log functional forms of the poultry-egg marketing functions were run using ordinary least square analysis. The estimated functions were evaluated in terms of statistical significance of the coefficients of multiple determinations $\left(\mathrm{R}^{2}\right)$, F-value, significance of coefficients and magnitude of standard errors. Based on these statistical and economic criteria, the double log functional form was selected as the lead equation. The adjusted R-square $\left(\mathrm{R}^{2}\right)$ was 0.891 , which implies that $89.1 \%$ variation in the dependent variable is accounted for by the specified independent variables. The F-value 29.425 was significant at $1 \%$ alpha level. Results further showed that stock size significantly influenced gross margin positively $(\mathrm{p} \leq$ $0.001)$ while cost price ( $\mathrm{p} \leq 0.001)$, labour cost $(\mathrm{p} \leq 0.01)$ and transportation cost $(\mathrm{p} \leq$ 0.001 ) had inverse significant relationship with the gross margin in poultry-egg marketing. The result shows that stock size, cost price, labour cost and transportation cost were significant variables influencing gross margin in the study area. On the stock 
size, it shows that one unit increase in stock size would increase the gross margin by 491.8 percent and as the cost price increases there would be a decrease in the gross margin by 387.9 percent. The labour cost is significant at $10 \%$ which implies that a one naira increase in the labour cost would affect the gross margin negatively by a decrease of 9.56 percent. Also, transportation cost is significant at $1 \%$ and it has negative effect on the gross margin. This implies that as transportation cost increases by one naira, the gross margin would decrease by 39.5 percent.

\section{Conclusion}

The study showed that poultry-egg marketing in the study area is a profitable business and as means of livelihoods to generate income. However, poultry-egg marketing business is faced with the problems of inadequate capital and price fluctuations. Moreover, gross margin in poultry-egg marketing is influenced by labour cost, transportation cost, and stock size, among others. Poultry-egg marketing should be encouraged since it serves as source of income, employment and means of livelihoods. Poultry-egg marketing helps in wealth creation thus alleviate poverty, hunger and malnutrition among the households.

\section{Recommendations}

The study showed that poultry-egg marketing generates income for the households, hence, poultry-egg marketers should be given access to credit and the markets for eggs should be organized with adequate storage facilities. Moreover, poultry-egg marketers should mobilize themselves into cooperative societies to enhance their access to finance/capital for their marketing business. The costs of feeds and other inputs used in poultry-egg production should be subsidized so as to make the market more profitable.

\section{References}

Central Bank of Nigeria, 2010. Annual Report and Statement of Accounts. CBN Publications. Abuja, Nigeria.

Food and Agriculture Organization, 1990. The State of Food and Agriculture, Vol. 4. Rome. Pg 65-72

Greene, W. H. 2002. Econometric Analysis $5^{\text {th }}$ Edition New York University, Pretence Hall, New Jersey

Iwena, O. A. 2007. Essential of Agricultural Science for Schools and Colleges Tonad Publishers Enugu, Nigeria. Pp 56-69

NPC 2006. National Population Commission. Population Census of the Federal Republic of Nigeria; Draft Report 2006.

Olanloye, A. 1998. Economics of Poultry Production in Ogun State, Nigeria. M.Sc. Agricultural Thesis, University of Agriculture, Abeokuta.

Okafor, R.M., Odii,M. A., Emayonu, C. A. and Obih, K. T. 2007. Profitability Analysis of Poultry Production in Imo State, Nigeria. Tropical Journal of Animal Science, 1(3):392-397.

Tijani, A. A., Alimi, T. and Adesiyan, A. T. 2006. Profit Efficiency among Nigerian Poultry-egg Farmers: A Case Study of Aiyedoto Farm Settlement, Nigeria. Researchers Journal of Agriculture and Biological Sciences, 2(6):256-261

Dietary for the Americans 2015-2020: Dietary Publications pp2-21

Received: $16^{\text {th }}$ August, 2020 Accepted: $20^{\text {th }}$ December, 2020 